\title{
PRODUCTION, UTILIZATION AND CONSTRAINTS OF DESHO GRASS (Pennisetum glaucifolium) AS LIVESTOCK FEED IN ETHIOPIA
}

\author{
Mergia ABERA1* ${ }^{*}$, Adugna TOLERA², Ajebu NURFETA² and Diriba GELETI ${ }^{3}$ \\ ${ }_{1}^{1}$ Southern Agricultural Research Institute, Hawassa Agricultural Research Centre, P.O. Box 06, Hawassa, Ethiopia \\ 2School of Animal and Range Science, College of Agriculture, Hawassa University, P.O.Box 05, Hawassa, Ethiopia \\ ${ }^{3}$ Ethiopian Institute of Agricultural Research, P.O.Box 2003, Addis Ababa, Ethiopia \\ Email: aberamergiya02@gmail.com; (D) ORCiD: 0000-0002-4084-713X \\ Supporting Information
}

\begin{abstract}
The study was conducted with the objective of assessing farmers' production practice, utilization and constraints of Desho grass (Pennisetum glaucifolium) production in Chencha, Bule and Hula districts, Ethiopia. The methodology of this study encompassed questionnaire survey and group discussion. Simple random sampling was used to select a sample consisting of 199 households in the districts. The collected data were analyzed by SPSS and SAS software. The result indicated that of the total respondents, $69 \%$ did not used fertilizer and $72 \%$ respondents not practiced weeding, Generally, the majority of respondents, did not use any forage improvement practice after plantation. Concerning forage utilization, 48.2, plant Desho as soil band, while $26.6 \%$ plant as hedgerows and $25.1 \%$ plant in the back yard. $40.2 \%$ of the respondents reported that they plant Desho grass for both feeding animals and soil conservation, while the remaining $36.7 \%$ plant Desho only for feeding animals, $20 \%$ plant Desho gras for sale and $3 \%$ plant Desho grass for only soil conservation. Based on the laboratory result, Desho grass is classified as high quality feedstuff for the study area. The crude protein, neutral detergent fiber, acid detergent fiber, acid detergent lignin content and in vitro organic matter digestibility of sample Desho grass was 7.04, 72.47, 43.73, 5.4 and 52.19 percent, respectively. Land shortage and lack of awareness were ranked first and second constraints for Desho production in the study area. It can be conclude that, Desho grass have a very important function in terms of contribution of nutrients to livestock and locally available feed resource however, farmers are not getting the benefits they deserve from the use of Desho grass, which has not been improved and should be supported by research to improve it production and use.
\end{abstract}

Keywords: Desho grass, Feed, Forage, Production practice, Utilization.

\section{INTRODUCTION}

In Ethiopia, the livestock sub-sector has significant contributions to the national income (Mengistu, 2012; Wondimagegnhu et al., 2019) and the livelihoods of households. However, livestock productivity is very low attributable to different factors of which poor nutrition is the major one. The livestock production is constrained by feed shortage in terms of both quantity and quality (Duguma et al., 2017). The feed resources are natural pasture, crop residues, agroindustrial by products; improve forage and weeds from cropland. Productivity of natural pasture is gradually decreasing due to rapidly increasing human population pressure, cropping is expanding and grazing areas are shrinking, leading to a shortage of livestock feed (Tolera, 2007; Duguma and Janssens, 2021).

Among the recommended mitigation strategies of feed shortage in the country is the utilization of indigenous adaptable multi-purpose fodder species such as Desho grass. Desho grass is indigenous to Ethiopia, which is highly popular and widely cultivated in southern Ethiopia as source of livestock feed (Smith, 2010). The grass is also widely used in soil and water conservation activities to combat land degradation and to improve productivity of land (Yakob et al., 2015). Farmers in many parts of Ethiopian highlands adopted Desho grass production because of its merits as animal feed and in soil and water conservation and management (Yakob et al., 2015; Umer et al., 2019). It has the potential to meet the challenges of feed scarcity as it gives high biomass yield per unit area and ensures year round forage supply due to its rapid growth and drought tolerance (Danano, 2007; Shiferaw et al., 2011). However, improved production and utilization practices of Desho grass are also very important besides the introduction and popularization of Desho grass by small-scale farmers (Mengistu et al., 2012, 2021).

Assessment of production and utilization of Desho grass have been survived at specific location (Burie zuria and Doyogena districts) in Ethiopia in earlier studies (Asmare et al., 2017). The study of Asmare et al. (2017) focused on the determinants of alternative and competing uses of the Desho grass and has little information on production practices of Desho grass. Previous study on Desho grass has focused on the potential value of the grass for soil and water conservation without considering its feed value, production and utilization (Yakob et al., 2015). The report by Smith (2010) and Danano (2007) indicated that the origin of Desho grass was Chencha district in Southern Nations, Nationalities, and Peoples' Regional States of Ethiopia. However, there is lack of information with regard to production and utilization of the grass in Chencha. 
Identification of constraints to improved forage technologies in a given agricultural system helps to design appropriate interventions. Beshir (2014) indicated that since the adoption of improved technologies is dynamic having information about the current technologies being adopted by farmers is very important. Knowledge of their production management, utilization and constraints are important to identify intervention for efficient utilization (Beyene and Fayessa, 2007). However, despite its abundance and expansion in different parts of the country, there is little available information with regard to status of Desho production and utilization practices, as well as, constraints to integrate into the farming system in southern Ethiopia. Therefore, the objective of this study was to assess the production, utilization and constraints of Desho grass in southern Ethiopia.

\section{MATERIALS AND METHODS}

\section{Description of study areas}

The study was conducted in selected district (Chencha) of Gamo zone and Bule district of Gedeo zone of Southern Nations, Nationalities, and Peoples Regional States of Ethiopia and in Hula district of Sidama Regional State of Ethiopia (Figure 1). The climate of Chencha, Hula and Bule districts are characterized as high altitude agro-ecology, where the farming system of the study areas is mixed crop-livestock production system. The rainfall pattern is characterized by two rainy seasons (main and short seasons). The main rainy season extends from June to October and the short rainy seasons from March to April (Dersseh et al., 2016).

Chencha district located in the Gamo Zone of southern region, 37 kilometers north of Arba Minch, Chencha has a longitude and latitude of $6^{\circ} 15^{\prime} \mathrm{N} 37^{\circ} 34^{\prime} \mathrm{E}$ and an elevation of 2732 meters above sea level. The minimum air temperature ranges from 11 to $13{ }^{\circ} \mathrm{C}$ and the maximum ranges from 18 to $24{ }^{\circ} \mathrm{C}$. The average annual rainfall is 1172 $\mathrm{mm}$ (Dersseh et al., 2016). Hula district geographically located between $6^{\circ} 03^{\prime}$ North latitude and $38^{\circ} 31^{\prime}$ East longitude about $90 \mathrm{~km}$ far from the regional capital city. The district has an elevation ranging from 2100-3200 meter above sea level and temperature range $10-18^{\circ} \mathrm{C}$. The rainfall pattern of the area is bimodal and receives ranging from $1100-1400$ $\mathrm{mm}$ per annum (Egziabher et al., 2020). Bule district is situated $120 \mathrm{~km}$ to south of, Hawassa city; and $27 \mathrm{~km}$ from Dila town. Geographically it lies between $6^{\circ} 04^{\prime}-6^{\circ} 23^{\prime}$ North latitude and $38^{\circ} 16^{\prime}-38^{\circ} 26^{\prime}$ East longitudes. The mean annual rain fall of Bule district ranges from $1,200 \mathrm{~mm}-1,800 \mathrm{~mm}$ and the mean annual temperature in degree Celsius is between $15.1^{\circ} \mathrm{C}$ and $22.5^{\circ} \mathrm{C}$ (Keteam et al., 2015).

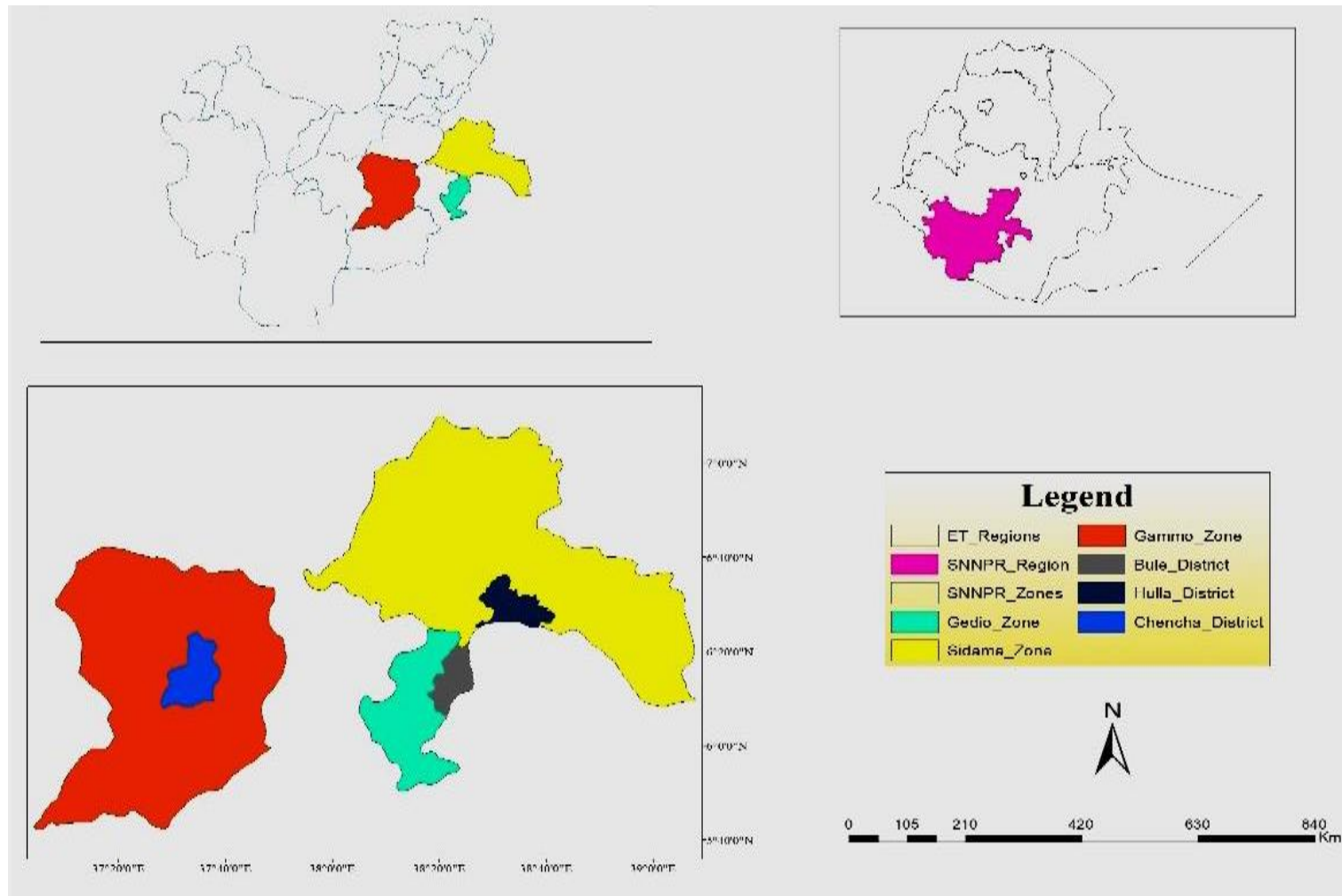

Figure 1 - Map of the study area

\section{Chemical analysis}

Chemical analysis of forages representative samples of Desho grass was taken from all study areas (chencha, Bule and Hula). After weighing, the biomass yield samples were mix together and $500 \mathrm{~g}$ of representative samples were used for laboratory work. The air-dried samples were analyzed for Dry Matter (DM), Ash, Crude Protein (CP), Neutral Detergent Fiber (NDF), Acid Detergent Fiber (ADF) and Acid Detergent Lignin (ADL). 


\section{Data collection and statistical analysis}

The survey was conducted in Chencha and Bule districts of Southern Nations, Nationalities, and Peoples' Regional States of Ethiopia and in Hula district of Sidama Regional State. The study districts were selected based on Desho grass production and utilization practices. From each district, two Kebeles were selected purposively based on wider availability and utilization of Desho grass. The house holds selected randomly and the number of households were 80,59 and 60 from Chencha, Hula and Bule, respectively proportional to their population. The sample size was calculated according to the formula of Yamane (1967). The survey was conducted using a semi-structured questionnaire completed as a personal interview. The data were complemented with information obtained from key informants, comprised of elder farmers from each Kebeles, including animal science and natural resource experts. The discussion were made with using prepared checklist.

Livestock holding per household was converted to standard units (Tropical Livestock Unit, i.e.one TLU = $250 \mathrm{~kg}$ ) based on conversion factors set previously (ILCA, 1990). Rank index was calculated according to the formula of Mekonnen et al. (2012). The overall rank of the Desho grass production constraints were calculated as following: Index = the sum of $\left(5\right.$ times first order +4 times $2^{\text {nd }}$ order +3 times $3^{\text {rd }}$ order +2 time $4^{\text {th }}$ order +1 times $5^{\text {th }}$ order) for individual variables divided by the sum of $\left(5\right.$ times first order +4 times $2^{\text {nd }}$ order +.3 times $3^{\text {rd }}$ order +2 time $4^{\text {th }}$ order +1 times $5^{\text {th }}$ order) for all variables.

Household survey data was analyzed using statistical package for social science (SPSS, version, 20). Descriptive statistics (percentage, mean and standard error) were used as a preliminary investigation procedure to gain an understanding of inherent significant socio-economic characteristics of the smallholder farmers. Further, data on livestock and land holding and land use pattern of the surveyed households were systematically coded and analyzed using general linear model of SPSS. Data were analyzed using SPSS version 20 for descriptive statistics and one way analysis of variance in which the three districts (the Chencha, Hula and Bule districts) of the study area were used as fixed factors. Duncan's new multiple range tests was used to determine the differences (statistical significance) between districts, mean values for the quantitative parameters at $5 \%$ level of significance. The statistical model used to analyze the quantitative data was: $Y i j=\mu+A i+e i j ;$ where, $Y i j=$ response variable, $\mu=$ overall mean, $A i=$ effect of districts and eij $=$ random error.

\section{RESULTS AND DISCUSSION}

\section{Livestock, land holding and land use pattern of the households}

The average tropical livestock units (TLU) and landholding (ha) per household and land use patterns of the respondents are presented in Table 1. Average family size was 6.71 person. Each family owned on average 4.56 TLU, which were maintained on a farm size of 1.51 ha. Average experience with Desho grass production was 2.15 years and average land size allocated for Desho grass was 0.01 ha. The current survey showed that the average livestock, land allocated for Desho grass and total land holding per household in Hula district was higher $(P<0.05)$ than Chencha and Bule districts. The average land allocated for Desho grass per household in Bule district was higher $(P<0.05)$ than Hula and Chencha districts could be due to increase the awareness on Desho grass as animal feed and government advocate planting of Desho grass in the slope land as soil conservation in addition to animal feed. Farm size is an important factor which normally determines the adoption of improved forages (Yami and Markel, 2008). The experience with Desho grass production in Chencha districts was more $(P<0.05)$ than Hula and Bule districts could be due to the grass was first planted and used at chencha district in Southern Nations Nationalitiesand Peoples' Region. Welle et al. (2006) reported that Desho grass is native to the highlands of Ethiopia. It was discovered as a species in 1991 in the Chencha district of the southern region of Ethiopia. The average family size was not significantly different among locations. Desho grass is considered as improved forage because it requires allocation of resources such as land, fertilizer and labor in addition to management practices (Asmare et al., 2017). With regard to landing holding, the average land size of (1.51 ha) in the current study is smaller than that reported by Admasu (2008) where average farm sizes were 2.55 ha per household in Southern Nations, Nationalities, and Peoples' Regional States of Ethiopia. On small farms, a greater percentage of the available area may be required to provide food for the family, leaving less to grow forage for livestock. Zereu and Lijalem (2016) reported that land shortage was major obstacle in highland of Ethiopia.

Table 1 - Family size, livestock and land holding and experience in Desho cultivation

\begin{tabular}{|c|c|c|c|c|c|}
\hline Parameters & $\begin{array}{l}\text { Chencha } \\
(N=80)\end{array}$ & $\begin{array}{c}\text { Hula } \\
(N=59)\end{array}$ & $\begin{array}{c}\text { Bule } \\
(N=60)\end{array}$ & $\begin{array}{c}\text { Total } \\
(\mathrm{N}=199)\end{array}$ & SL \\
\hline Family size [Mean $( \pm \mathrm{SE})]$ & $6.60 \pm 2.28$ & $6.27 \pm 1.19$ & $7.28 \pm 3.01$ & $6.71 \pm 2.73$ & Ns \\
\hline Livestock holding (TLU) & $3.02 \pm 1.63^{b}$ & $7.46 \pm 3.89 a$ & $3.79 \pm 3.89 b$ & $4.56 \pm 3.43$ & ** \\
\hline Total land (ha) & $1.07 \pm 0.49^{b}$ & $2.67 \pm 0.82^{a}$ & $0.95 \pm 0.61^{b}$ & $1.51 \pm 0.99$ & ** \\
\hline Land for Desho grass (ha) & $0.01 \pm 0.02^{b}$ & $0.01 \pm 0.01^{b}$ & $0.02 \pm 0.03$ & $0.01 \pm 0.02$ & ** \\
\hline Experience in Desho grass cultivation (yr.) & $2.95 \pm 0.78^{a}$ & $1.46 \pm 0.63^{c}$ & $1.77 \pm 0.81^{b}$ & $2.15 \pm 0.10$ & ** \\
\hline
\end{tabular}




\section{Feed shortage and coping strategies}

Shortage of feed was the major problem reported by all respondents in all districts (Figure 2). In Chencha district, 93.8\% of respondents faced seasonal feed shortage, with $56.3 \%$ of these experiencing the problem only during the dry season, while the remaining $\mathbf{4 3 . 8 \%}$ faced shortage in both dry and wet seasons. In Hula district, $98.3 \%$ of respondents faced feed shortages, $55.9 \%$ of these in the dry season only and the remaining $44.1 \%$ in both wet and dry seasons. In Bule district, $\mathbf{9 5 . 0 \%}$ of respondents faced feed shortages, $55.8 \%$ of these in the dry season only and the remaining $44.2 \%$ in both wet and dry seasons. The major problem of livestock production in current study districts was shortage of feed in both dry and wet seasons is in agreements with previous studies in different parts of the country (Shapiro et al., 2015; Abule et al., 2017). Asmare et al. (2016) who reported that 98.3\% in Burie Zuria and 99.2\% in Doyogena district faced seasonal feed shortage, which is similar to the present finding. Feed shortage coping strategies employed in all three districts were similar, with only the proportions differing between districts. In Chencha district, strategies were: use of crop residue only (43.8\%), use crop residue plus Enset leaf (47.5\%) and crop residue plus rented grazing land (8.8\%). Corresponding values in Hula district were $32.2,50.8$ and $16.9 \%$, respectively, and in Bule district were $31.7,60.0$ and $8.3 \%$, respectively (Figure 3 ).

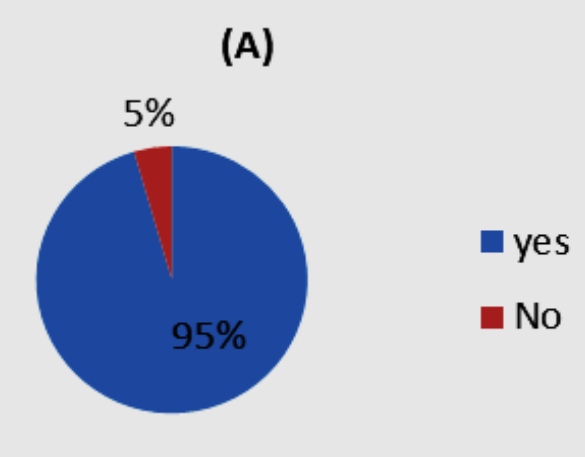

Figure 2 - The mean perceived feed shortage (A) and time of scarcity (B)

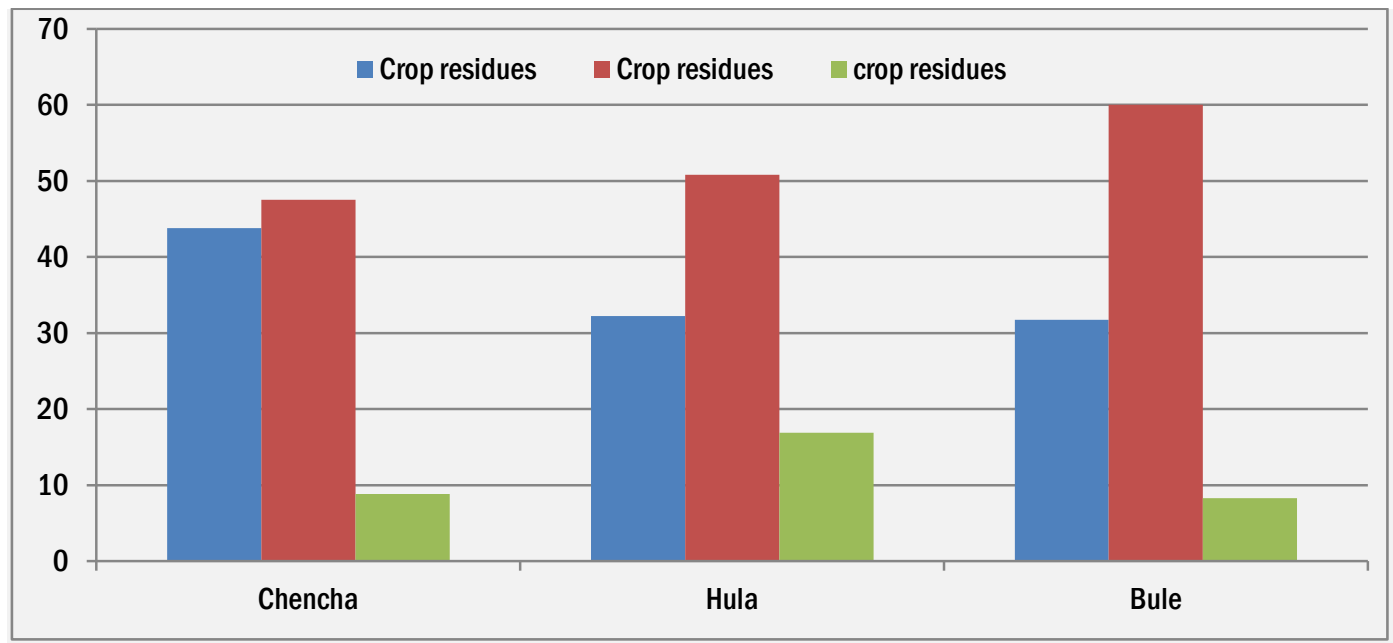

Figure 3 - Feed shortage mitigation strategies by respondents in the three districts (\%)

Rainfall or irrigation used for Desho grass production

The cultivation of Desho grass in the study areas were dependent on rainfall (92\%), while the remaining (8\%) used irrigation (Figure 4). In Chencha district $90 \%$ of respondents depended on rain for Desho grass production, while $10 \%$ had access to irrigation. In Hula district $\mathbf{9 8 . 3} \%$ of respondents depended on rain for Desho grass production, while $\mathbf{1 . 7 \%}$ had access to irrigation. In Bule district $\mathbf{8 8 . 3} \%$ of respondents depended on rain for Desho grass production, while $\mathbf{1 1 . 7 \%}$ had access to irrigation. The current study is in agreement with previous study of Asmare et al. (2016) who reported that $80 \%$ in Burie Zuria and in Doyogena district all depended only on rainfall, which is lower than present finding.

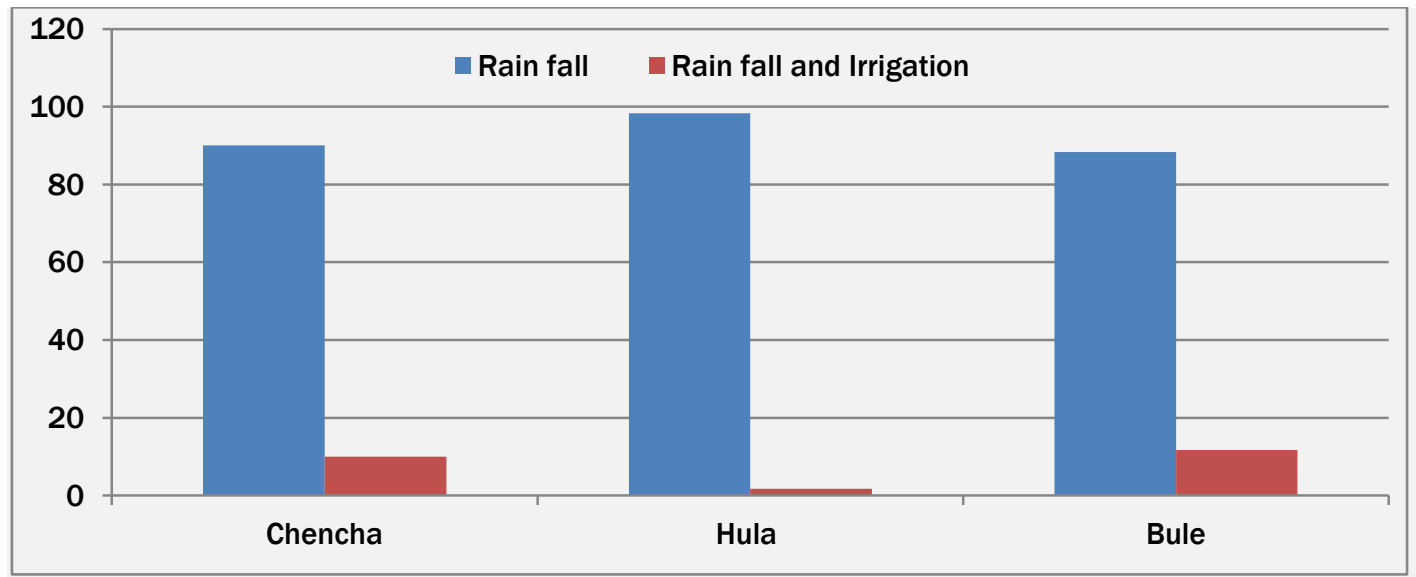

Figure 4 - Sorce of of water (rain fall or irrigation) for Desho grass production 


\section{Type and time of fertilizer utilization for Desho grass production}

The majority of respondents were not utilizing fertilizer (69.3\%), while the remaining $1 / 3(30.7 \%)$ used fertilizer. Gerba et al. (2013) reported that fertilizer application in the form of manure or artificial fertilizer is important for Desho grass production. Asmare et al. (2016) who reported that $58 \%$ in Burie Zuria and $65 \%$ in Doyogena district applied either manure or artificial fertilizer to the Desho grass, which is higher than the present finding. High costs of fertilizer, lack of awareness on use of fertilize and farmers' assumption for their land is fertile are the main reasons for not using fertilizer. However, fertilizer usage was not uniform in either the application or form of fertilizer. The majority of respondents used manure $(70.9 \%)$ while the remaining $15.6 \%$ used compost and $13.6 \%$ used chemical fertilizer (Table 2). The majority (23.1\%) of respondents were applying fertilizer at planting, while the remaining (21.6\%) applying fertilizer twice a year and (19.6\%) applying fertilizer once a year.

\section{Time and frequency of weeding for Desho production}

The majority of respondents not practiced weeding (71.9\%), while the remaining practiced weeding $(28.1 \%)$. The majority of respondents did the weeding if there are weed on the Desho grass (25.6\%) while the remaining did the weeding at rainy season (20.6\%). The majority of respondents did the weeding twice a year (23.6\%), while the remaining did the weeding once a year (5.5\%) and $3 \%$ times a year (Table 3 ). The current study is contrast with previous study of Asmare et al. (2017) who reported that weeding of Desho grass was practiced neither Burie zuria nor Doyogena district.

\section{Table 2 - Type and time of fertilizer utilization for Desho grass production}

\begin{tabular}{|c|c|c|c|c|c|c|c|c|c|}
\hline \multirow[t]{2}{*}{ Variables } & \multicolumn{2}{|c|}{ Chencha $(\mathrm{N}=\mathbf{8 0})$} & \multicolumn{2}{|c|}{$\begin{array}{c}\text { Hula } \\
(\mathrm{N}=59)\end{array}$} & \multicolumn{2}{|c|}{$\begin{array}{c}\text { Bule } \\
(\mathrm{N}=60)\end{array}$} & \multicolumn{2}{|c|}{$\begin{array}{c}\text { Total } \\
(\mathrm{N}=199)\end{array}$} & \multirow{2}{*}{ Chi-square } \\
\hline & $\%$ & Freq. & $\%$ & Freq. & $\%$ & Freq. & $\%$ & Freq. & \\
\hline \multicolumn{10}{|l|}{ Fertilizer application } \\
\hline Yes & 23.8 & 19 & 23.7 & 14 & 46.7 & 28 & 30.7 & 61 & \multirow[t]{2}{*}{$22.16 *$} \\
\hline No & 76.2 & 61 & 76.3 & 45 & 53.3 & 32 & 69.3 & 138 & \\
\hline \multicolumn{10}{|l|}{ Reason for not using fertilizer } \\
\hline $\begin{array}{l}\text { Soil is fertile enough for Desho } \\
\text { growth }\end{array}$ & 15.0 & 12 & 20.3 & 12 & 16.7 & 10 & 17.1 & 34 & \multirow[t]{3}{*}{$21.80 *$} \\
\hline Lack of awarness & 36.2 & 29 & 5.1 & 3 & 38.3 & 23 & 27.6 & 55 & \\
\hline High cost of fertilizer & 48.8 & 39 & 74.6 & 44 & 45.0 & 27 & 55.3 & 110 & \\
\hline \multicolumn{10}{|l|}{ Type of fertilizer } \\
\hline Chemical fertilizer & 7.5 & 6 & 5.1 & 3 & 30 & 18 & 13.6 & 27 & \multirow{3}{*}{$10.36 *$} \\
\hline Manure & 71.3 & 57 & 81.3 & 48 & 60 & 36 & 70.8 & 141 & \\
\hline Compost & 21.2 & 17 & 13.6 & 8 & 10 & 6 & 15.6 & 31 & \\
\hline \multicolumn{10}{|l|}{ Time of application } \\
\hline At planting & 16.2 & 13 & 13.6 & 8 & 41.7 & 25 & 23.1 & 46 & \multirow{4}{*}{$95 *$} \\
\hline Once a year & 21.3 & 17 & 32.2 & 19 & 5 & 3 & 19.6 & 39 & \\
\hline Twice a year & 50.0 & 40 & 0 & 0 & 5 & 3 & 21.6 & 43 & \\
\hline Not used & 12.5 & 10 & 54.2 & 32 & 48.3 & 29 & 35.7 & 71 & \\
\hline
\end{tabular}

\begin{tabular}{|c|c|c|c|c|c|c|c|c|c|}
\hline \multirow{2}{*}{ Variables } & \multicolumn{2}{|c|}{$\begin{array}{l}\text { Chencha } \\
(\mathrm{N}=80)\end{array}$} & \multicolumn{2}{|c|}{$\begin{array}{c}\text { Hula } \\
(\mathrm{N}=59)\end{array}$} & \multicolumn{2}{|c|}{$\begin{array}{c}\text { Bule } \\
(\mathrm{N}=60)\end{array}$} & \multicolumn{2}{|c|}{$\begin{array}{c}\text { Total } \\
(\mathrm{N}=199) \\
\end{array}$} & \multirow{2}{*}{ Chi-square } \\
\hline & $\%$ & Freq. & $\%$ & Freq. & $\%$ & Freq. & $\%$ & Freq. & \\
\hline \multicolumn{10}{|l|}{ Weeding practices } \\
\hline Yes & 11.3 & 9 & 27.1 & 16 & 51.7 & 31 & 28.1 & 56 & \multirow[t]{2}{*}{$27.72 *$} \\
\hline No & 88.8 & 71 & 72.9 & 43 & 48.3 & 29 & 71.9 & 143 & \\
\hline \multicolumn{10}{|l|}{ Time of weeding } \\
\hline if there are weed & 7.5 & 6 & 25.4 & 15 & 50 & 30 & 25.6 & 51 & \multirow{3}{*}{$77.32 *$} \\
\hline At rainy season & 3.8 & 3 & 30.5 & 18 & 33.3 & 20 & 20.6 & 41 & \\
\hline None & 88.8 & 71 & 44.1 & 26 & 16.7 & 10 & 53.8 & 107 & \\
\hline \multicolumn{10}{|l|}{ Frequency of weed } \\
\hline Once & 2.5 & 2 & 3.4 & 2 & 11.7 & 7 & 5.5 & 11 & \multirow{4}{*}{$19.46^{*}$} \\
\hline Twice & 18.8 & 15 & 20.3 & 12 & 33.3 & 20 & 23.6 & 47 & \\
\hline Three time & 0 & 0 & 3.4 & 2 & 6.7 & 4 & 3 & 6 & \\
\hline None & 78.8 & 63 & 729 & 43 & 48.3 & 29 & 67.8 & 135 & \\
\hline
\end{tabular}

\section{Spacing between plants and rows for Desho grass production}

The majority of respondents' practiced row planting $(75.9 \%)$, while the remaining $24.1 \%$ did not practice row planting (Table 4). In all study districts, the main spacing between plants was $50 \mathrm{~cm}$ and greater than $50 \mathrm{~cm}$ with equal 
percentage $(34.7 \%)$ of respondents following this practice. However, the majority of respondents were used $50 \mathrm{~cm}$ between rows $(79.9 \%)$ while the remaining $(20.1 \%)$ used $100 \mathrm{~cm}$.

\section{Planting time and planting material used for Desho grass production}

Majority of respondents used root spilt as planting material (79.9\%), while the remaining (20.1\%) used cuttings as planting mattering. High survival rate and fast growth nature of root split are the two main reasons for use of root split as planting material. The majority of respondents were planting two cutting per hole $(48.2 \%)$, while the remaining $22.6 \%$ plant three cutting per hole, $18.8 \%$ plant greater than three cutting per hole and $10.6 \%$ planting one cutting per hole (Table 5). The majority (45.2\%) of respondents were planting in July, while the remaining (42.7\%) were planting in June while some (12.1\%) was planting in April (Table 5).

\section{Planting strategies used for Desho grass production}

Majority of respondents planted Desho as soil band (48.2\%), while $26.6 \%$ planted as hedgerows and $25.1 \%$ plant in the back yard (Table 6). This may be because the strategy is more convenient for the cut and carry feeding system, enabling intensive management and thus high yields in areas where land shortage is a problem. The current study contrast with findings of Asmare et al. (2016) who reported that in Burie Zuria and doyogena districts, the dominant form of Desho grass production was as a backyard enterprise with $86.3 \%$ of respondents following this practice.

\section{Table 4 - Spacing between plants and rows for Desho grass production}

\begin{tabular}{|c|c|c|c|c|c|c|c|c|c|}
\hline \multirow{2}{*}{ Variables } & \multicolumn{2}{|c|}{ Chencha $(\mathrm{N}=\mathbf{8 0})$} & \multicolumn{2}{|c|}{ Hula $(N=59)$} & \multicolumn{2}{|c|}{ Bule $(\mathrm{N}=60)$} & \multicolumn{2}{|c|}{ Total $(\mathrm{N}=199)$} & \multirow{2}{*}{ Chi-square } \\
\hline & $\%$ & Freq. & $\%$ & Freq. & $\%$ & Freq. & $\%$ & Freq. & \\
\hline \multicolumn{10}{|c|}{ Planting in row or not } \\
\hline Yes & 87.5 & 70 & 45.8 & 27 & 90 & 54 & 75.9 & 151 & $41.68 *$ \\
\hline No & 12.5 & 10 & 54.2 & 32 & 10 & 6 & 24.1 & 48 & \\
\hline \multicolumn{10}{|c|}{ Spacing between plants } \\
\hline$<50 \mathrm{~cm}$ & 10 & 8 & 49.2 & 29 & 40 & 24 & 30.7 & 61 & \\
\hline $50 \mathrm{~cm}$ & 33.8 & 27 & 15.3 & 9 & 55 & 33 & 34.7 & 69 & $59 *$ \\
\hline$>50 \mathrm{~cm}$ & 56.3 & 45 & 35.6 & 21 & 5 & 3 & 34.7 & 69 & \\
\hline \multicolumn{10}{|c|}{ Spacing between rows } \\
\hline $50 \mathrm{~cm}$ & 63.8 & 51 & 89.8 & 53 & 91.7 & 55 & 79.9 & 159 & 21.79 * \\
\hline $100 \mathrm{~cm}$ & 36.3 & 29 & 10.2 & 6 & 8.3 & 5 & 20.1 & 40 & \\
\hline
\end{tabular}

Table 5 - Planting time and planting material used for Desho grass production in study area

\begin{tabular}{|c|c|c|c|c|c|c|c|c|c|}
\hline \multirow{2}{*}{ Variables } & \multicolumn{2}{|c|}{ Chencha $(\mathrm{N}=80)$} & \multicolumn{2}{|c|}{ Hula $(\mathrm{N}=59)$} & \multicolumn{2}{|c|}{ Bule $(\mathrm{N}=60)$} & \multicolumn{2}{|c|}{ Total $(\mathrm{N}=199)$} & \multirow{2}{*}{ Chi-square } \\
\hline & $\%$ & Freq. & $\%$ & Freq. & $\%$ & Freq. & $\%$ & Freq. & \\
\hline \multicolumn{10}{|l|}{ Month of planting } \\
\hline April & 3.8 & 3 & 0 & 0 & 35 & 21 & 12.1 & 24 & \multirow{3}{*}{$50.48 *$} \\
\hline June & 55 & 44 & 50.8 & 30 & 18.3 & 11 & 42.7 & 85 & \\
\hline July & 41.3 & 33 & 49.2 & 29 & 46.7 & 28 & 45.2 & 90 & \\
\hline \multicolumn{10}{|c|}{ Number of cuttings perhole } \\
\hline One & 6.3 & 5 & 5.1 & 3 & 21.7 & 13 & 10.6 & 21 & \multirow{4}{*}{$31.31 *$} \\
\hline Two & 61.3 & 49 & 52.5 & 31 & 26.7 & 16 & 48.2 & 96 & \\
\hline Three & 26.3 & 21 & 16.9 & 10 & 23.3 & 14 & 22.6 & 45 & \\
\hline$>$ Three & 6.3 & 5 & 25.4 & 15 & 28.3 & 17 & 18.8 & 37 & \\
\hline \multicolumn{10}{|l|}{ Part of plant used } \\
\hline Cutting & 11.3 & 9 & 25.4 & 15 & 26.7 & 16 & 20.1 & 40 & \multirow[t]{2}{*}{$6.56 *$} \\
\hline Root spilt & 88.8 & 71 & 74 & 44 & 73.3 & 44 & 79.9 & 159 & \\
\hline \multicolumn{10}{|c|}{ Reason for using root split } \\
\hline Fast growth & 56.3 & 45 & 39 & 23 & 45 & 27 & 47.7 & 95 & \multirow[t]{2}{*}{$4.32^{\text {ns }}$} \\
\hline High survival rate & 43.8 & 35 & 61 & 36 & 55 & 33 & 52.3 & 104 & \\
\hline
\end{tabular}

Table 6 - Planting strategies used for Desho grass production

\begin{tabular}{|c|c|c|c|c|c|c|c|c|c|}
\hline \multirow{2}{*}{ Variables } & \multicolumn{2}{|c|}{ Chencha $(\mathrm{N}=\mathbf{8 0})$} & \multicolumn{2}{|c|}{ Hula $(\mathbf{N}=59)$} & \multicolumn{2}{|c|}{ Bule $(\mathrm{N}=60)$} & \multicolumn{2}{|c|}{ Total $(\mathbf{N}=199)$} & \multirow{2}{*}{ Chi-square } \\
\hline & $\%$ & Freq. & $\%$ & Freq. & $\%$ & Freq. & $\%$ & Freq. & \\
\hline \multicolumn{10}{|l|}{ Planting strategies } \\
\hline Backyard & 20 & 16 & 23.7 & 14 & 33.3 & 20 & 25.1 & 50 & \multirow{3}{*}{$12.30 *$} \\
\hline Hedge rows & 22.5 & 18 & 40.7 & 24 & 18.3 & 11 & 26.6 & 53 & \\
\hline Soil band & 57.5 & 46 & 35.6 & 21 & 48.3 & 29 & 48.2 & 96 & \\
\hline
\end{tabular}


Time of harvesting and feeding form of Desho grass

The majority of respondents harvested the Desho grass when there a need $(48.7 \%)$ while the remaining $31.7 \%$ looking the biomass yield and $19.6 \%$ depend on the plant height of the grass. The majority of respondents were harvest at 2-month interval (41.2\%) while the reminder (32.7\%) depend on rainfall and $26.1 \%$ greater than 2 weeks of interval (Table 7). The current study not agrees with findings of Asmare et al. (2016) who reported that frequency of cuts for Burie Zuria district every 2 weeks (44.7\%), more than 2 weeks (20.3\%), depends on rain/moisture availability (35\%); and for Doyogena, every 2 weeks (23.8\%), and depends on rain/moisture availability (74.6\%). The majority of respondents were feeding Desho grass as fresh $(80.4 \%)$, while $19.6 \%$ used in the form of hay.

\section{Access of training on Desho grass production}

Majority of respondents were not trained on Desho production and utilization (77.9\%), while the remaining $22.1 \%$ had training (Table 8). This suggests that effort should be made to provide training and information on production and utilization Desho grass. The current study disagrees with findings of Asmare (2016) who reported that $70 \%$ of farmers in Burie Zuria have received training in Desho grass production.

\section{Use of Desho grass in the study area}

Desho grass has multiple uses for the small holder farmers (Table 9). Majority of the respondents (40.2\%) reported that they plant Desho grass for both feeding animals and soil conservation, while the remaining $36.7 \%$ plant Desho only for feeding animals, 20\% plant Desho grass for sale and 3\% plant Desho grass for only soil conservation. The non-feed roles of the grass are as soil conservation and income source by selling the grass to other farmers. The current study in agrees with Danano (2007) who reports that Desho grass also provides a small business opportunity for farmers. There was no difference $(P>0.05)$ between district as income source for Desho grass. Significant difference $(P<0.05)$ was found for feed and soil conservation, which was higher at the Chencha (52.5\%) and Bule (51.7\%) than Hula (11.9\%). This might be due to the difference in the topography of the districts, in chancha and Bule districts, as the topography is more mountainous and grazing is limited. Thus, Desho grass was planted for both soil conservation and feed purpose. The current study is in line with findings of Tegegne et.al. (2013) who reported that farmers in many parts of Ethiopian highlands showed adoption of Desho grass production because of its merits as animal feed and in soil and water conservation and management. Desho grass was used for both soil conservation and feed purposes in all the study districts, as reported by other workers (Welle et al., 2006; Leta et al., 2013). Shortage of feed was the major problem in all study districts could be due to limitations of grazing land, exposure of soil towards erosion and high density of livestock per household create a higher potential for Desho grass to be utilized as both feed and for soil conservation in the study area.

\section{Table 7 - Time of harvesting feeding form of Desho grass production}

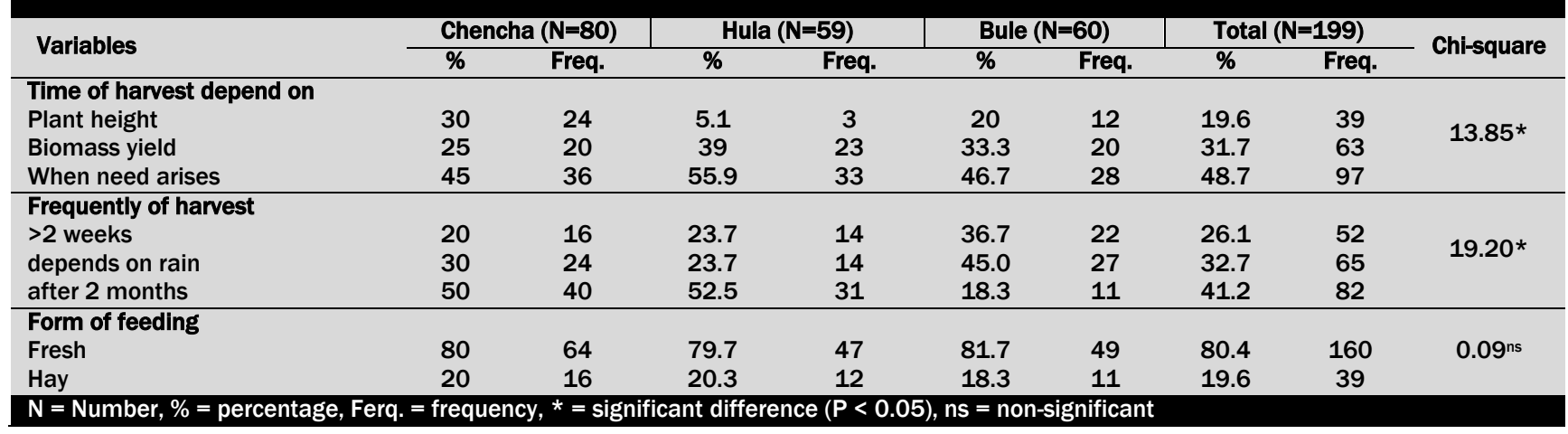

Table 8 - Access of training on Desho grass production and utilization

\begin{tabular}{|c|c|c|c|c|c|c|c|c|c|}
\hline \multirow{2}{*}{ Variables } & \multicolumn{2}{|c|}{ Chencha $(\mathrm{N}=\mathbf{8 0})$} & \multicolumn{2}{|c|}{ Hula $(\mathrm{N}=59)$} & \multicolumn{2}{|c|}{ Bule $(\mathbf{N}=60)$} & \multicolumn{2}{|c|}{ Total $(\mathrm{N}=199)$} & \multirow{2}{*}{ Chi-square } \\
\hline & $\%$ & Freq. & $\%$ & Freq. & $\%$ & Freq. & $\%$ & Freq. & \\
\hline \multicolumn{10}{|c|}{ Access to trainings? } \\
\hline Yes & 22.5 & 18 & 11.9 & 7 & 31.7 & 19 & 22.1 & 44 & $6.79 *$ \\
\hline No & 77.5 & 62 & 88.1 & 52 & 68.3 & 41 & 77.9 & 155 & \\
\hline
\end{tabular}

\section{Table 9 - Use of Desho grass in study area}

\begin{tabular}{|c|c|c|c|c|c|c|c|c|c|}
\hline \multirow{2}{*}{ Variables } & \multicolumn{2}{|c|}{ Chencha $(\mathrm{N}=\mathbf{8 0})$} & \multicolumn{2}{|c|}{ Hula $(\mathrm{N}=59)$} & \multicolumn{2}{|c|}{ Bule $(\mathrm{N}=60)$} & \multicolumn{2}{|c|}{ Total $(\mathrm{N}=199)$} & \multirow{2}{*}{$\begin{array}{c}\text { Chi- } \\
\text { square }\end{array}$} \\
\hline & $\%$ & Freq. & $\%$ & Freq. & $\%$ & Freq. & $\%$ & Freq. & \\
\hline \multicolumn{10}{|l|}{ Use of Desho grass } \\
\hline Feed & 21.3 & 17 & 69.5 & 41 & 25 & 15 & 36.7 & 73 & \\
\hline Soil conservation & 7.5 & 6 & 0 & 0 & 0 & 0 & 3 & 6 & 50.87 * \\
\hline Feed \& soil conservation & 52.5 & 42 & 11.9 & 7 & 51.7 & 31 & 40.2 & 80 & \\
\hline Sale & 18.8 & 15 & 18.6 & 11 & 23.3 & 14 & 20.1 & 40 & \\
\hline
\end{tabular}




\section{Priority of feeding Desho grass to different class of livestock}

The majority of respondents feed Desho grass to large ruminants $(47.7 \%)$, while 38.2 and $14.1 \%$ of the respondents reported that they give preference of feeding Desho grass for all animal and small ruminants, respectively (Table 10). The current study agrees with the findings of Asmare (2016) who reported that $42 \%$ of farmers who fed Desho grass did so to only lactating cattle, $3 \%$ fed it to small ruminants and $53 \%$ fed it to all livestock species. However, percentage was not uniform in priority of feeding Desho grass to different class of livestock.

\section{Trends of Desho production in the study area}

Majority (71.4\%) of the respondents stated that the trend of Desho grass utilization as livestock feed is increasing from time to time (Table 11). Many factors triggered the increasing use of Desho grass as animal feed. Critical feed shortage is the main driver given by the respondents for the increasing interest in including Desho grass production.

\section{Constraints of Desho grass production in study area}

Constraints of Desho grass production in the study area are presented in Table 12. Responders identified land shortage, both land shortage and lack of awareness, lack of awareness, land shortage and lack of planting material, labor, market and planting material as the major constraints for Desho production in the study areas. Among these six factors, land shortage was ranked as the major constraint for Desho cultivation in the study area. Lack of awareness on Desho grass production and utilization was ranked as a second constraint. The respondents reported that they have not received training on production and utilization of Desho grass. Labor and market problem also influenced Desho production in the study areas. Planting material was ranked last in terms of its influence on Desho production and utilization. The current study is in agreement with previous study of Assefa et al., (2015) who reported that shortage of land $\left(1^{\text {st }}\right)$, high expense of forage planting materials $\left(2^{\text {nd }}\right)$ and lack of awareness $\left(3^{\text {rd }}\right)$ were the main constraints hindering adoption of improved forages in Shashogo district of Hadiya zone, southern Ethiopia. Zereu and Lijalem (2016) reported that land shortage $\left(1^{\text {st }}\right)$, lack and high cost of planting materials $\left(2^{\text {nd }}\right)$, poor extension service $\left(3^{\text {rd }}\right)$, drought $\left(4^{\text {th }}\right)$ and lack of awareness $\left(5^{\text {th }}\right)$ as the major constraints for improved forage cultivation in Wolaita Zone, Southern Ethiopia.

\section{Table 10 - Priority of feeding Desho grass to livestock}

\begin{tabular}{|c|c|c|c|c|c|c|c|c|c|}
\hline \multirow{2}{*}{ Variables } & \multicolumn{2}{|c|}{ Chencha $(\mathrm{N}=\mathbf{8 0})$} & \multicolumn{2}{|c|}{ Hula $(\mathrm{N}=59)$} & \multicolumn{2}{|c|}{ Bule $(\mathrm{N}=60)$} & \multicolumn{2}{|c|}{ Total $(\mathrm{N}=199)$} & \multirow{2}{*}{ Chi-square } \\
\hline & $\%$ & Freq. & $\%$ & Freq. & $\%$ & Freq. & $\%$ & Freq. & \\
\hline \multicolumn{10}{|l|}{ Desho prioritize to feeding } \\
\hline Yes & 66.3 & 53 & 59.3 & 35 & 53.3 & 32 & 60.3 & 120 & $2.43^{\text {ns }}$ \\
\hline No & 33.8 & 27 & 40.7 & 24 & 46.7 & 28 & 39.7 & 79 & \\
\hline \multicolumn{10}{|l|}{ For which Animals? } \\
\hline Large ruminants (Cattle) & 52.5 & 42 & 45.8 & 27 & 43.3 & 26 & 47.7 & 95 & \\
\hline Small ruminants & 13.8 & 11 & 20.3 & 12 & 8.3 & 5 & 14.1 & 28 & $6.04^{\mathrm{ns}}$ \\
\hline All animals & 33.3 & 27 & 33.9 & 20 & 48.3 & 29 & 38.2 & 76 & \\
\hline
\end{tabular}

Table 11 - Trends in Desho grass production as livestock feed

\begin{tabular}{|c|c|c|c|c|c|c|c|c|c|}
\hline \multirow{2}{*}{ Variables } & \multicolumn{2}{|c|}{ Chencha $(\mathbf{N}=\mathbf{8 0})$} & \multicolumn{2}{|c|}{ Hula $(\mathrm{N}=59)$} & \multicolumn{2}{|c|}{ Bule $(N=60)$} & \multicolumn{2}{|c|}{ Total $(\mathrm{N}=199)$} & \multirow{2}{*}{ Chi-square } \\
\hline & $\%$ & Freq. & $\%$ & Freq. & $\%$ & Freq. & $\%$ & Freq. & \\
\hline \multicolumn{10}{|l|}{ Trends of Desho Production } \\
\hline Increasing & 38.8 & 31 & 100 & 59 & 86.7 & 52 & 71.4 & 142 & \multirow{3}{*}{75.44 * } \\
\hline Decreasing & 23.8 & 19 & 0 & 0 & 0 & 0 & 9.5 & 19 & \\
\hline As usual (no change) & 37.5 & 30 & 0 & 0 & 13.3 & 8 & 19.1 & 38 & \\
\hline
\end{tabular}

Table 12 - Major constraints of Desho grass production in study area by ranks weight index rank

\begin{tabular}{|c|c|c|c|c|c|c|c|}
\hline Constraints & $1^{\text {st }}$ & $2^{\text {nd }}$ & $3^{\text {rd }}$ & $4^{\text {th }}$ & $5^{\text {th }}$ & Index & Rank \\
\hline Land shortage & 87 & 30 & 8 & 5 & 0 & 0.329 & 1 \\
\hline Land shoratge and lack of awareness & 50 & 25 & 10 & 7 & 0 & 0.220 & 2 \\
\hline Lack of Awareness & 36 & 15 & 5 & 3 & 2 & 0.147 & 3 \\
\hline Land shortage \& lack of planting material & 11 & 20 & 15 & 5 & 4 & 0.108 & 4 \\
\hline Labor shortage & 5 & 10 & 15 & 10 & 5 & 0.076 & 5 \\
\hline Market problem & 2 & 5 & 4 & 3 & 1 & 0.027 & 6 \\
\hline Lack of planting material & 8 & 10 & 15 & 16 & 8 & 0.092 & 7 \\
\hline Total & 199 & 115 & 72 & 49 & 20 & 1.000 & \\
\hline
\end{tabular}

Index sum of [( $5 \times$ number of responses for $1^{\text {st }}$ rank $)+\left(4 \times\right.$ number of responses for $2^{\text {nd }}$ rank $)+\left(3 \times\right.$ number of responses for $3^{\text {rd }}$ rank $)+(2 \times$

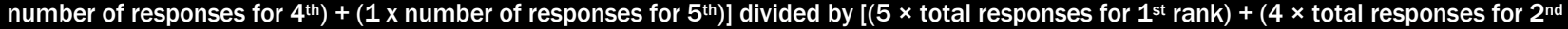
rank $)+\left(3 \times\right.$ total responses for $3^{\text {rd }}$ rank $)+(2 \times$ total responses for 4 th rank $)+\left(1 \times\right.$ number of responses for $\left.\left.5^{\text {th }}\right)\right]$. 


\section{Chemical composition of Desho grass}

Dry Matter (DM), Crude Protein (CP), Ash, Neutral Detergent Fiber (NDF), Acid Detergent Fiber (ADF) and Acid Detergent Lignin (ADL) are parameters used to evaluate sample Desho grass in (Table 13). The dry matter (DM) content of all sample fresh forges was 89. The CP content of Desho grass in the current study is comparable with the findings (7.12\%) of Waziri et al. (2013). The CP content (7.33\%) reported by Asmare et al. (2017) for Desho grass is higher than the current finding. The difference observed in CP content might be attributable to the stage of the harvest of the Desho grass as it has been reported by Asmare et al. (2017) that young (90 days after planting) Desho grass had higher CP content $(9.33 \%)$ than the mature (150 days) ones $(6.93 \%)$. Also, the difference observed might be attributable to the difference in altitude associated with photosynthesis and nutrient assimilation as it has been reported by Asmare et al. (2017) that lowland Desho grass had higher CP content $(9.33 \%)$ than the highland one (7.33\%). The difference observed in the chemical composition of the feeds might be attributable to the stage of the harvest and altitude.

Table 13 - Chemical composition and in vitro organic matter digestibility (\% DM basis) of Desho grass

\begin{tabular}{|c|c|c|c|c|c|c|c|}
\hline \multirow{2}{*}{ Sample name } & \multicolumn{6}{|c|}{ Chemical composition (\%) } & \multirow[b]{2}{*}{ IVOMD } \\
\hline & DM & Ash & $\mathbf{C P}$ & NDF & ADF & ADL & \\
\hline Desho grass hay & 89 & 10.35 & 7.04 & 72.47 & 43.73 & 5.29 & 52.19 \\
\hline
\end{tabular}

The neutral detergent fiber (NDF) content of sample Desho grass was $72.47 \%$. Singh and Oosting (1992) pointed out that roughage feeds containing NDF values of less than $45 \%$ could be classified as high quality, those with values ranging from $45 \%$ to $65 \%$ as medium and those with values higher than $65 \%$ as low quality. Based on it, Desho grass can be classified as low-quality feed, But the NDF value mainly depends on the time of cutting date, when forages cut at 112 days their quality becomes high but their biomass yield becomes low than Desho grass harvested 154 days (Mergia et al., 2020). The acid detergent fiber (ADF) content of sample Desho grass was 43.73. According to Kellems and Church (2011), roughage with less than $40 \%$ ADF are categorized as high quality and those with greater than $40 \%$ as poor quality. Based on the laboratory result, Desho grass is classified as high-quality feedstuff for the study area.

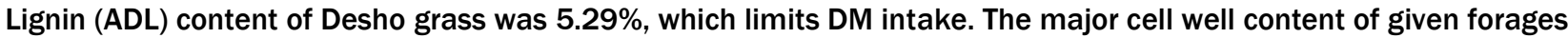
was mainly depending on age of the plant. When the plant becomes aged, the cell well content becomes very hard on the contrary; when the plant becomes young, the cell well part becomes more palatable.

\section{CONCLUSION}

The result of current study showed that the majority of the farming households in the study area predominantly use Desho grass as feed sources and soil conservation. The study revealed that use of Desho grass as livestock feed by smallholder farmers' has been steadily increasing over the past few years. Critical feed shortage is the main driver given by the respondents for the increasing interest in including Desho grass production. Land shortage and lack of awareness were ranked first and second constraints for Desho production. Based on the laboratory result, Desho grass is classified as high quality feedstuff for the study area. Overall, Desho grass have a very important function in terms of contribution of nutrients to livestock and locally available feed resource however, farmers are not getting the benefits they deserve from the use of Desho grass, which has not been improved and should be supported by research to improve it production and use. Therefore, it can be conclude that intervention on the management and utilization practices of the Desho grass need to be done

\section{DECLARATIONS}

\section{Corresponding Author}

E-mail: aberamergiya02@gmail.com

I contribute on the write up of the proposal, data collection, data analysis and the write up of the manuscript

\section{Conflict of interests}

The authors have not declared any conflict of interests.

\section{Acknowledgements}

The author appreciates the Southern Agricultural Research Institute for sponsoring this study. The author also thank Chencha, Hula and Bule districts office of Agriculture and rural development office who facilitated condition for survey study, and the farmers who participated in the interview.

\section{Author`s Authors Contribution}

Mergia Abera participated in the design of study, performed the experiments and writing original manuscript. Adugna Tolera, Ajebu Nurfeta, Diriba Geleti critically revised, and editing the manuscript for important intellectual contents. 


\section{REFERENCES}

Abera M, Tolera A, Nurfeta A and Geleti D (2017) Effect of Fertilizer Level and Harvesting Date on Yield and Nutritive Value of Desho Grass (Pennisetum pedicellatum) in Hula and Bule districts of the Southern Region of Ethiopia. Ethiopian Journal of Animal production. 2020. 20(1):18-28.

Abule E, Girma A, Engida O. Livestock feed resources in Southern Ethiopia: the case of Meskan district. Livestock Research for Rural Development. 29(11). Google Scholar

Admassu YM (2008). Assessment of livestock feed resources utilization in Alaba Woreda, Southern Ethiopia (Doctoral dissertation, Haramaya University). https://cgspace.cgiar.org/handle/10568/694 doi.org/10.1016/i.anres.2016.11.001

Asmare B, Demeke S, Tolemariam T, Tegegne F, Haile A, Wamatu J. (2017). Effects of altitude and harvesting dates on morphological characteristics, yield and nutritive value of desho grass (Pennisetum pedicellatum Trin.) in Ethiopia. Agriculture and Natural Resources. 51(3):148-53. DOI: https://doi.org/10.1016/j.anres.2016.11.001

Asmare B, Demeke S, Tolemariam T, Tegegne F, Wamatu J, Rischkowsky B (2016). Determinants of the utilization of desho grass (Pennisetum pedicellatum) by farmers in Ethiopia. Tropical Grasslands-Forrajes Tropicales. 4(2):112-21. D0I: https://doi.org / 10. 17138/ TGFT(4)112121

Assefa F, Ano T, Aba T, Ebrahim Z (2015). Assessment of improved forage types and their utilization in Shashogo Woreda, Hadiya zone, Southern Ethiopia. Global Journal of Animal Science, Livestock Production and Animal Breeding. 3(6):227-30. Google Scholar

Beshir H (2014). Factors affecting the adoption and intensity of use of improved forages in North East Highlands of Ethiopia. Journal of Experimental Agriculture International. 2014: 12-27. DOI: https://doi.org/10.9734/AJEA/2014/5481

Beyene H and Fayessa F (2007). Crop Residue Utilization and Management in Different Farming Systems of Ethiopia. Crop Residues. $2007: 101$. Google Scholar I Direct link

Danano D (2007). Improved grazing land management- Ethiopia. In H. Liniger, \& W. Critchley (Eds,), Where the land is greener. Bern, Switzerland: WOCAT. Pp 313-316

Dersseh WM, Gebresilase YT, Schulte RP, Struik PC (2016). The analysis of potato farming systems in Chencha, Ethiopia: input, output and constraints. American Journal of Potato Research. 93(5):436-47. DOI: https://doi.org/10.1007/s12230-016-9521-9

Duguma B, Janssens GP (2021). Assessment of Livestock Feed Resources and Coping Strategies with Dry Season Feed Scarcity in Mixed CropLivestock Farming Systems around the Gilgel Gibe Catchment, Southwest Ethiopia. Sustainability. 13(19): 10713. D0I: https://doi.org/10.3390/su131910713

Duguma B, Dermauw V, Janssens G (2017). The assessment and the farmers' perceived ranking of feed resources and coping strategies with feed scarcity in smallholder dairy farming in selected district towns of Jimma Zone, Ethiopia. Tropical animal health and production. 49(5):923-35. DOI: https://doi.org/10.1007/s11250-017-1274-z

Egziabher YG, Kebede F, Mengistu DK, Tadesse HK, Mahari M, Welday Y (2020). Indigenous knowledge and socio-economic significance of Enset (Ensete ventricosum (Welw.) Cheeseman) cultivation and food processing in Sidama, Southern Ethiopia. Ethnobotany Research and Applications. 19: 1-7. https://ethnobotanyjournal.org/era/index.php/era/article/view/1767

ILCA (International Livestock Centre for Africa). Livestock System Research Manual. Working Paper No. 1,Vol. 1. ILCA, Addis Ababa, Ethiopia. 1990. Dec; 1-341. https://cgspace.cgiar.org/bitstream/handle/10568/4317/wp12-vol1.pdf?sequence=1.Kellems R0, Church DC. Livestock feeds and feeding. Upper Saddle River, NJ: Prentice Hall; 2002. Google Scholar

Kellems RO, Church DC (1998). Livestock Feeds and Feeding (4th Edit.) Simon and Schuster. New Jersey, USA. 1998: 59-61. Google Scholar

Ketema H, Fita M, Bantider A (2015). Soil quality variation under Enset based conservation tillage and creal based conventional tillage system in Southern Highlands of Ethiopia. Advances in Plants \& Agriculture Research. 2015; 2. Google Scholar

Leta G, Duncan AJ, Abdena A (2013). Desho grass (Pennisetum pedicellatum) for livestock feed, grazing land and soil and water management on small-scale farms. Google Scholar

Mengistu A (2012). Keynote address. In: Getnet Assefa, Mesfin Dejene, Jean Hanson, Getachew Anemut, Solomon Mengistu And Alemayehu Mengistu (eds), Forage seed research and development in Ethiopia. Ethiopia institute of agricultural research, Addis Ababa, Ethiopia. 3-5. https://cgspace.cgiar.org/handle/10568/32799

Mengistu S, Nurfeta A, Tolera A, Bezabih M, Adie A, Wolde-meskel E, Zenebe M (2021). Livestock Production Challenges and Improved Forage Production Efforts in the Damot Gale District of Wolaita Zone, Ethiopia. Advances in Agriculture. 2021. D0I: https:// doi.org/ 10. 1155/ $2021 / 5553659$

Mekonnen A, Haile A, Dessie T, Mekasha Y (2012). On farm characterization of Horro cattle breed production systems in western Oromia, Ethiopia. Livestock Research for Rural Development. 24: 6-17. Google Scholar

Shapiro BI, Gebru G, Desta S, Negassa A, Negussie K, Aboset G, Mechal H. (2015). Ethiopia livestock master plan: Roadmaps for growth and transformation. Google Scholar

Shiferaw A, Puskur R, Tegegne A, Hoekstra D (2011). Innovation in forage development: empirical evidence from Alaba Special District, southern Ethiopia. Development in Practice. 21(8): 1138-52. https://doi.org/10.1080/09614524.2011.591186

Singh GP, Oosting SJ (1992). A model for describing the energy value of straws. Indian dairyman. 1992. Google Scholar

Smith G (2010). Ethiopia: Local solutions to a global problem. Retrieved from View. 2010. Google Scholar

Tegegne A, Gebremedhin B, Hoekstra D, Belay B, Mekasha Y (2013). Smallholder dairy production and marketing systems in Ethiopia: IPMS experiences and opportunities for market-oriented development. Google Scholar

Tolera A (2007). Feed resources for producing export quality meat and livestock in Ethiopia. Ethiopia Sanitary and Phytosanitary Standards and Livestock and Meat Marketing project (SPS-LMM). 2007; 77. Google Scholar

Umer S, Aticho A, Kiss E (2019). Effects of integrated use of grass strip and soil bund on soil properties, Southern Ethiopia. Journal of Degraded and Mining Lands Management. 6(2): 1569. DOI: https://doi.org/10.15243/jdmlm.2019.062.1569

Welle S, Chantawarangul K, Nontananandh S, Jantawat S. (2006). Effectiveness of grass strips as barrier against runoff and soil loss in Jijiga area, northern part of Somali region, Ethiopia. Agriculture and Natural Resources. 40(2): 549-58. Google Scholar

Wondimagegnhu BA, Huluka AT, Nischalke SM (2019). Determinants of farm livelihoods of smallholder farmers in Yayu biosphere reserve, SW Ethiopia: a gender disaggregated analysis. Cogent Economics \& Finance. 7(1): 1645583. https://doi.org/ 10.1080/ 23322039. 2019. 1645583

Yakob G, Ababa A (2015). Participatory evaluation of different multipurpose grass species for graded soil bund stabilization in Gimbo district, South West Ethiopia. Open Access Library Journal. 2(06):1. Google Scholar

Yamane T (1967). Statistics: an introductory analysis Harper and row. New York, Evanston and London and John Weather Hill. Inc., Tokyo. 1967. Google Scholar

Merkel RC, Yami A (2008). Sheep and Goat Production Handbook for Ethiopia. 2008. AGRIS

Zereu G, Lijalem T (2016). Status of improved forage production, utilization and constraints for adoption in Wolaita Zone, Southern Ethiopia. Livestock research for rural development. 28:78. Google Scholar 